\title{
Risk Factors for Cerebellar Mutism after Posterior Fossa Tumors Excision in Children
}

MOHAMMED H. ALY, M.D. and AHMAD H. ASHRY, M.D.

The Department of Neurosurgery, Faculty of Medicine, Cairo University

\begin{abstract}
Background: Post-operative cerebellar mutism is known complication may occur following the excision of posterior fossa tumors in paediatrics, specially seen with medulloblastoma lesions. Post-operative Cerebellar Mutism (CM).

Aim of Study: Post-operative cerebellar mutism is not uncommon after excision of posterior fossa tumors in pediatrics. Evaluation of important risk factors e.g. type of tumor, size, site and infiltration of brainstem was studied in this work.

Material and Methods: A series of 30 children with posterior fossa tumors were operated at Abo El-Reesh Hospital, Department of Neurosurgery in 2017. Their radiological data and neurocognitive functions were investigated pre and postoperatively.

Results: Cerebellar mutism developed in 9 children ( $30 \%$ ) in the first few days post-operative, 7 males and 2 females. Age ranged from two years to twelve years. 7 cases were medulloblastoma and 2 cases were ependymom. There was infiltration of brainstem in most cases of cerebellar mutism. Mutism resolved in 8 cases.

Conclusion: Cerebellar mutism could often occur following excision of posterior fossa tumors in pediatrics in first days following the surgery with favourable outcome. It most likely occurs following the resection of medulloblastoma infiltrating brainstem. The cerebellar ischemia and the cerebellar edema may be possible causes for occurrence of cerebellar mutism.
\end{abstract}

Key Words: Posterior fossa-Children-MedulloblastomaMutism.

\section{Introduction}

POST-OPERATIVE cerebellar mutism is known complication may occur following the excision of posterior fossa tumors in paediatrics, specially seen with medulloblastoma lesions. Post-operative Cerebellar Mutism (CM), is defined as a situation of complete loss of speech which is not associated

Correspondence to: Dr. Mohammed H. Aly, The Department of Neurosurgery, Faculty of Medicine, Cairo with other causes of aphasia or other causes of disturbed conscious level e.g. hematoma or infarction.

Cerebellar mutism may occur as a part of syndrome called posterior fossa syndrome.

The percentage of Posterior Fossa Syndrome ( PFS), (also known as cerebellar mutism syndrome), ranging from 7 into $33 \%$ in the children with posterior fossa tumors $[\mathbf{1 , 2}]$.

In addition to post-operative cerebellar mutism, the PFS is sometimes associated with multiple neurological manifestations, e.g. pyramidal tract signs and neurobehavioral manifestations [3-5].

The cerebellar mutism usually starts one to two or three days following the surgery.

It may persist from one day to several months following surgery.

And sometimes it is followed with severe dysarthria before complete recovery [6].

Some cases may be associated with delayed onset post-operative cerebellar mutism which may occur 1 to 3 months following surgery [6].

The accurate mechanism for post-operative cerebellar mutism is still unknown, but multiple theories may be accepted in explanation of cerebellar mutism.

It is believed that direct relation between the mutism and the affection of dentate nuclei and

\footnotetext{
Abbreviations and Acronyms:

CCAS: Cerebellar Cognitive Affective Syndrome.

CMS : Cerebellar Mutism Syndrome.

CSF: Cerebrospinal Fluid.

PFS : Posterior Fossa Syndrome.
} 
their efferent cerebellothalamic-cerebral connections [7-9].

Other proposed mechanism for occurrence of mutism is cerebellar hypoperfusion injury with subsequent cerebellar ischemia.

Causes of hypoperfusion including: Vasospasm, axonal perioperative injury, post-operative edema and changes in neurotransmitter levels) [10].

In multiple studies, multiple factors for cerebellar mutism have been suggested such as type of lesion, size, location of the mass, the operative approach and Invasion of the brain stem [11,12].

The goal of the current study was to identify the percentage of cerebellar mutism and to study its relation to these risk factors.

\section{Material and Methods}

This is a prospective study conducted on thirty cases of pediatric posterior fossa tumors admitted to Neurosurgery Department of Specialized Pediatric University Hospital (Abul Reesh) between January 2017 and January 2018.

All patients were fully investigated by proper history taking, full general and neurological examination. CT brain was performed on admission for evaluation of associated hydrocephalus.

All patients were assessed by MRI brain with contrast pre-operatively, follow-up CT scans were conducted 24 hours post-operatively. All patients are subjected for follow-up period between 6 to 12 months post-operatively.

Post-operatively, all patients were followed for any changes in their neurological or psychologic conditions. Particularly, any changes in speech e.g. mutism and dysarthria, or any emotional changes such as irritability, emotional lability, crying and apathy are observed.

Motor tone and motor power are also assessed.

Any disturbance in gait or in balance are noted and followed.

Speech are assessed every day following surgery in all children.

In cases of mutism, they were followed-up at short intervals until sufficient improvement occurs.

The speech was evaluated for:

Spontaneous language, repetition of words and the ability to read, tone of speech, the articulation and the rate of speech.

\section{Results}

The data collected from 30 cases of surgically managed posterior fossa tumors was analysed ( Table 1).

Incidence: Cerebellar mutism occurring in 9 cases out of 30 case with percentage $30 \%$. Seven patients had medulloblastoma and two patients had ependymoma.

Age \& sex: Age of patients in this study extended from 2 years into 12 years, the median age was7 years.

There was a great male predominance. There were 18 males (60\%) and 12 females (40\%).

Mutism developing in 7 males and in 2 females.

\section{Clinical criteria and the outcome:}

Mutism developed early in first $48 \mathrm{hr}$ following the surgery in four patients and after 3-5 day's latencies in other five patients. Mutism persisted for 60 days in single patient. Mutism lasted between 5 and 28 days in seven patients. One patient in our study didn't improve with persistence of mutism for more than 6 months.

\section{Pathology and size of neoplasms:}

Cerebral mutism occurred in 7 of 12 patients with a medulloblastoma (58 \%) and 2 of 5 patients with ependymoma (40\%). Invasion of the brain stem and of the cerebellar peduncle was present in 6 patients.

The size of the medulloblastoma ranged from 3. $6 \mathrm{~cm}$ to $7.3 \mathrm{~cm}$ (mean $4.7 \mathrm{~cm}$ ). The size of the ependymoma ranged from $3.3 \mathrm{~cm}$ to $7.7 \mathrm{~cm}$ (mean 4 . $9 \mathrm{~cm})$.

\section{Surgical approaches:}

Telovelar approach was the most frequently surgical approach used in our study in 10 patients ( $33 \%)$, while the trans-vermian approach was used in 7 cases $(23 \%)$.

Other surgical approaches including transcortical (median and paramedian) and retrosigmoid was used in the remaining 13 patients.

Five cases out of nine cases of cerebral mutism occurring through telovelar approach while four cases occurring through trans-vermian approach.

Follow-up and recurrences: The average duration for follow-up was 9 months, ranging from 6 to 12 months. 
Table (1): Summary of the patients.

\begin{tabular}{|c|c|c|c|c|c|c|c|c|}
\hline $\begin{array}{l}\text { Case } \\
\text { no. }\end{array}$ & $\begin{array}{l}\text { Age } \\
\text { (yrs.) }\end{array}$ & Sex & $\begin{array}{l}\text { Localization } \\
\text { of tumour }\end{array}$ & Approach & $\begin{array}{l}\text { Degree of } \\
\text { excision }\end{array}$ & Mutism & Diagnosis & $\begin{array}{l}\text { Day of } \\
\text { starting } \\
\text { mutism }\end{array}$ \\
\hline 1 & $9 y$ & \multicolumn{2}{|c|}{ iv14th.ventricle } & Telo-velar & G.total & Yes & MEDULLO-BLASTOMA & 2nd day \\
\hline 2 & $11 y$ & $\mathrm{~F}$ & $4 \mathrm{t}^{\mathrm{h}} \cdot$ ventricle & Telo-velar & G.total & No & MEDULLO-BLASTOMA & None \\
\hline 3 & $8 \mathrm{y}$ & \multirow{26}{*}{ [ } & CEREBELLAR & PARA-MEDIAN & G.total & No & PILOCYTIC ASTROCYTOMA & None \\
\hline 4 & $8 y$ & & CEREBELLAR & PARA-MEDIAN & G.total & No & PILOCYTIC ASTROCYTOMA & None \\
\hline 5 & $4 y$ & & 4th.ventricle & Telo-velar & Subtotal & Yes & MEDULLO-BLASTOMA & 1st day \\
\hline 6 & $3 y$ & & 4th.ventricle & Telo-velar & G.total & Yes & MEDULLO-BLASTOMA & 3rd day \\
\hline 7 & $8 y$ & & $4 \mathrm{t}^{\mathrm{h}} \cdot$ ventricle & Trans vermian & Subtotal & Yes & MEDULLO-BLASTOMA & $3^{r}$ d day \\
\hline 8 & $5 y$ & & CEREBELLAR & PARA MEDIAN & G.total & No & Glioblastoma & None \\
\hline 9 & $7 y$ & & CEREBELLAR & Median & G.total & No & Hemangio-blastoma & None \\
\hline 10 & $5 y$ & & CEREBELLAR & Median & G.total & No & PILOCYTIC ASTROCYTOMA & None \\
\hline 11 & $10 y$ & & CEREBELLAR & Para median & G.total & No & PILOCYTIC ASTROCYTOMA & None \\
\hline 12 & $11 \mathrm{y}$ & & $4 \mathrm{t}^{\mathrm{h}}$. ventricle & Telo-velar & G.total & No & MEDULLO-BLASTOMA & None \\
\hline 12 & $2 y$ & & 4th.ventricle & Telo-velar & G.total & No & MEDULLO-BLASTOMA & None \\
\hline 13 & $4 y$ & & $4 \mathrm{t}^{\mathrm{h}}$.ventricle & Trans vermian & Subtotal & Yes & EPENDYMOMA & 2nd day \\
\hline 14 & $10 \mathrm{y}$ & & 4th.ventricle & Trans vermian & G.total & No & EPENDYMOMA & None \\
\hline 15 & $5 y$ & & $4 \mathrm{t}^{\mathrm{h}} \cdot$ ventricle & Telo-velar & Subtotal & No & EPENDYMOMA & None \\
\hline 16 & $10 \mathrm{y}$ & & CEREBELLAR & Median & G.total & No & Hemangio-blastoma & None \\
\hline 17 & $6 y$ & & CEREBELLAR & Para-median & G.total & No & PILOCYTIC ASTROCYTOMA & None \\
\hline 18 & $2 y$ & & CEREBELLAR & Median & G.total & No & Glioblastoma & None \\
\hline 19 & $4 y$ & & 4th.ventricle & Trans vermian & G.total & Yes & Ependymoma & 3rd day \\
\hline 20 & $11 \mathrm{y}$ & & $4 \mathrm{t}^{\mathrm{h}} \cdot$ ventricle & Trans vermian & Subtotal & No & MEDULLLO-BLASTOMA & None \\
\hline $\begin{array}{l}21 \\
21\end{array}$ & $5 y$ & & CPA & Retro-sigmoid & G.total & No & Epidermoid & None \\
\hline 21 & $6 y$ & & 4th.ventricle & Telo-velar & G.total & Yes & MEDULLO-BLASTOMA & 5th day \\
\hline 22 & $12 y$ & & CEREBELLAR & Median & G.total & No & Fibrillary astrocytoma & None \\
\hline 23 & $12 y$ & & 4th.ventricle & Telo-velar & G.total & No & MEDULLO-BLASTOMA & None \\
\hline 24 & $4 y$ & & CEREBELLAR & Median & G.total & No & Glioblastoma & None \\
\hline 25 & $6 y$ & & 4th.ventricle & Trans vermian & Subtotal & No & Ependymoma & None \\
\hline 26 & $7 y$ & & CEREBELLAR & Median & G.total & No & PILOCYTIC ASTROCYTOMA & None \\
\hline 27 & $5 y$ & \multirow{3}{*}{$\mathrm{F}$} & CEREBELLAR & Para-median & G.total & No & PILOCYTIC ASTROCYTOMA & None \\
\hline $\begin{array}{r}28 \\
20\end{array}$ & $8 \mathrm{y}$ & & 4th.ventricle & Trans vermian & G.total & Yes & MEDULLO-BLASTOMA & 3rd day \\
\hline & $2 y$ & & 4th.ventricle & Telo-velar & Subtotal & Yes & MEDULLO-BLASTOMA & 2nd day \\
\hline
\end{tabular}

G.total: Gross total. CPA : Cerebellopontine Angle.
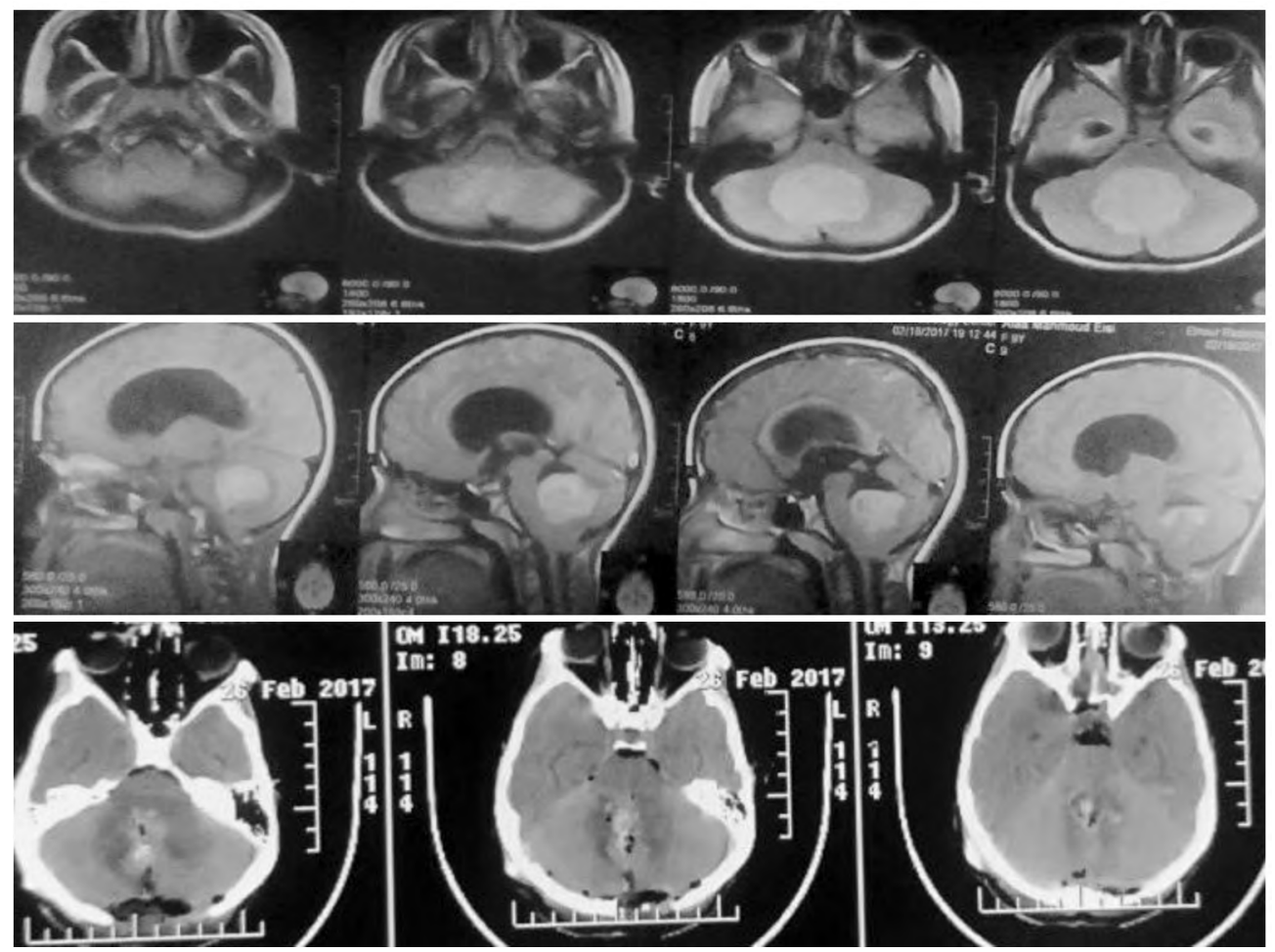

Fig. (1): Pre-operative MRI and post-operative C.T scan of 4y child with fourth ventricular ependymoma operated via transvermian route. 


\section{Discussion}

Cerebellar mutism after posterior fossa tumors excision was first described by Rekate et al. and Yonemasu in 1985 [13,14].

Mutism is defined as total loss of ability to speak without any manifestations related to aphasia and without loss of consciousness. The exact etiology of cerebellar mutism is still unknown. Cerebellar mutism has been documented more frequently in pediatric category [14]. One of most accepted theory may be damage (ischemic or edematous) to the dentate nucleus and dentatothalamocortical and dentorubrocortical pathways. This damage mostly due to post-operative spasm of the cerebellar arteries [15].

The rate of cerebellar mutism in various studies ranging from $10 \%$ to $25 \%$ [16,17].

Kusano reported that the post-operative cerebellar mutism associated with the bilateral damage to the dentate nuclei and not with the unilateral damage [18].

Doxey et al., reported in their group of twenty patients with cerebral mutism following posterior fossa tumor resection that the mutism recovered in all, but there was mild residual neurological deficits, specially ataxia, in all patients [12].

Steinbok et al., reported in their group of 7 patients with cerebral mutism which occurred in children, that the mutism did not recover except in single patient [19].

In current study the mutism was totally recovered in all patients except one patient with persistent of mutism for more than 6 months.

Transient mutism was also mentioned to be associated with vermian incision specially in children [13].

In this study, both transvermian approach and telovelar approache has no great difference in outcome of patients regarding the development of cerebellar mutism.

Cerebellar mutism occurred through telovelar approach in five cases in this study, while it occurred four times in patients with transvermian approach.

It was believed that post-operative cerebellar mutism was not significantly affected by type of the approach used in surgery.
Rajesh et al., operated 15 cases of pediatric midline 4th ventricular tumors with medulloblastoma predominance. They achieved gross total excision in 14 cases $(93 \%)$ through the telovelar approach. The mutism was mentioned in only 2 patients (13\%) [20].

Rajesh et al., mentioned that huge tumors extending to the rostral fourth ventricle may be linked with occurrence of cerebellar mutism as more dissection is often associated with more retraction and with more tissue damage [20].

He believed that post-operative mutism can be avoided by good surgical technique through proper dissection with less retraction and less tissue damage [20].

Van Calenbergh et al., retrospectively studied series of 63 patients below the age of sixteen years undergoing transvermian approach. Cerebellar mutism was observed only in 5 cases (8\%) [21].

Brain stem infiltration occurred in four patients of the five patients with cerebellar mutism in Van Calenbergh study.

In our study brain stem invasion occurred in six of nine cases.

There was no sex predilection for cerebellar mutism in multiple previous studies $[\mathbf{6 , 1 2 , 2 2 ]}$.

Male predominance was very clear in our study.

Younger age patients may be considered as a possible risk factor for cerebellar mutism as a fact this syndrome is described less frequently in adults. This may be due to Incomplete maturation of pathways between cerebellum and pontine nuclei, thalamus, sensory and motor areas in pediatrics $[23,24]$.

Doxey et al., found that histopathological type of the tumor especially the medulloblastoma type, are associated with higher incidence of postoperative cerebellar mutism [12].

This previous finding is totally consistent with our results as 7 cases out of 9 cases of cerebellar mutism in this study were for patients with medulloblastoma tumor.

\section{Conculsion:}

Cerebellar mutism could often occur following excision of posterior fossa tumors in pediatrics in the first days following the surgery with favourable outcome. It most likely occurs following the resection of medulloblastoma infiltrating brainstem. 
The cerebellar ischemia and edema may be possible causes for occurrence of cerebellar mutism.

\section{References}

1- SIFFERT J., POUSSSAINT T.Y., GOUMNEROVA L.C., SCOTT R.M., LaVALLEY B., TARBELL N.J. and POMEROY S.L.: Neurological dysfunction associated with post-operative cerebellar mutism. J. Neurooncol. May, 48 (1): 75-81, 2000.

2- RIVA D. and GIORGI C.: The cerebellum contributes to higher functions during development. Brain, 5: 105-1061, 2000.

3- VAN MOURIK M., VAN DONGEN H.R. and CATSMAN-BERREVOETS C.E.: The many faces of acquired neurologic mutism in childhood. Pediatr. Neurol., 15 (4): 352-7, 1996.

4- VAN DONGEN H.R., CASTMAN-BERREVOTS C.E. and VAN MOURIK M.: The syndrome of 'cerebellar' mutism and subsequent dysarthria. Neurology, 44 (11): 2040-6, 1994.

5- WOLFE-CHRISTENSEN C., MULLINS L.L., SCOTT J. G., et al.: Persistent psychosocial problems in children who develop posterior fossa syndrome after medülloblastoma resection. Pediatr Blood Cancer, 49: 723-6, 2007.

6- CATSMAN-BERREYOETS C.E., VAN DONGEN H.R., MULDER P.G., PAZY GEUZE D., PAQUIER P.F. and LEQUIN M.H.: Tumour type and size are high risk factors for the syndrome of "cerebellar" mutism and subsequent dysarthria. J. Neurol. Neurosurg. Psychiatry. Dec., 67 (6): 755-7, 1999.

7- POLLACK I.F., POLINKO P., ALBRIGHT A., TOWBIN R. and FITZ C.: Mutism and pseudobulbar symptoms after resection of posterior fossa tumors in children: Incidence and pathophysiology. Neurosurgery, 37: 88593, 1995

8- VAN BAARSEN K.M. and GROTENHUIS J.A.: The anatomical substrate of cerebellar mutism. Med. Hypotheses, 82: 774-80, 2014.

9- LAW N., GREENBERG M., BOUFFET E., TAYLOR M. D., LAUGHLIN S., STROTHER D., et al.: Clinical and neuroanatomical predictors of cerebellar mutism syndrome. Neuro. Oncol., 14: 1294-303, 2012.

10- AVULA S., MALLUCCI C., KUMAR R. and PIZER B.: Posterior fossa syndrome following brain tumour resection: Review of pathophysiology and a new hypothesis on its pathogenesis. Childs Nerv. Syst., 31: 1859-67, 2015.

11- RICHTER S., SCHOCH B., KAISER O., et al.: Behavioral and affective changes in children and adolescents with chronic cerebellar lesions. Neurosci. Lett., 381: 102-7, 2005.
12- DOXEY D., BRUCE D., SKLAR F., SWIFT D. and SHAPIRO K.: Posterior fossa syndrome: Identifiable risk factors and irreversible complications. Pediatr. Neurosurg. ,31 (3): 131-316, 1999.

13- REKATE H.L., GRUBB R.L., ARAM D.M., HAHN J.F. and RATCHESON R.A.: Muteness of cerebellar origin. Arch. Neurol., 43: 697-8, 1985.

14- YONEMASU Y.: Cerebellar mutism and speech disturbance as a complication of posterior fossa surgery in children. 13th Annual Meeting Japanese Soc. Ped. Neurosurg. Tsukuba, 1985.

15- JONES S., KIROLLOS R.W. and VAN HILLE P.T.: Cerebellar mutism following posterior fossa tumour surgery. Br. J. Neurosurg. Apr., 10 (2): 221-4, 1996 Review.

16- AGUIAR P.H., PLESE J.B., CIQUINI O. and MARINO R.: Transient mutism following a posterior fossa approach to cerebellar tumors in children: A critical review of the literature. Childs Nerv. Syst. May, 11 (5): 306-10, 1995 Review.

17- AL- ANAZI A., HASSAOUNAH M., SHEIKH B. and BARAYAN S.: Cerebellar mutism by arteriovenous malformation of the vermis. Br. J. Neurosurg., 15: 47-50, 2001.

18- KUSANO Y., TANAKA Y., TAKASUNA H., WADA N., TADA T., KAKIZAWA Y. and HONGO K.: Transient cerebellar mutism caused by bilateral damage to the dentate nuclei after the second posterior fossa surgery. Case report. J. Neurosurg., 104: 329-31, 2006.

19- STEINBOK P., COCHRANE D.D., PERIN R. and PRICE A.: Mutism after posterior fossa tumor resection in children: Incomplete recovery on long-term follow-up. Pediatr. Neurosurg., 39 (4): 179-83, 2003.

20- RAJESH B.J., RAO B.R., MENON G., ABRAHAM M., EASWER H.V. and NAIR S.: Telovelar approach: Technical issues for large fourth ventricle tumors. Childs Nerv. Syst. May, 23 (5): 555-8. Epub Feb. 15, 2007.

21- VAN CALENBERGH F., VAN De LAAR A., PLETS C., GOFFIN J. and CASAER P.: Transient cerebellar mutism after posterior fossa surgery in children. Neurosurgery, Nov., 37 (5): 894-8, 1995.

22- KOTIL K., ERAS M., AKCETIN M. and BILGE T.: Cerebellar mutism following posterior fossa tumor resection in children. Turk. Neurosurg., Vol.: 18, No.: 1, 8994, 2008.

23- OZGUR B.M., BERBERIAN J., ARYAN H.E., et al.: The pathophysiologic mechanism of cerebellar mutism. Surg. Neurol., 66: 18-25, 2006.

24- ILDAN F., TUNA M., ERMAN A., et al.: The evaluation and comparison of cerebellar mutism in children and adults after posterior fossa surgery: Report of two adult cases and review of the literature. Acta Neurochir., 144: 


\section{عوامل الخطر للطفرات الدماغية الحماتية

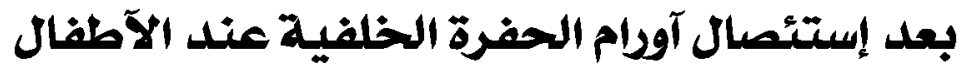

الخرس المخيخى بعد العملية الجراحية ليس من غير المالوف بعد إستئصال آودام الحفرة الخلفية في طب الآطفال. تقييم عوامل الخطر

الهامة مثل دراسة نوع الودم وحجمه وموقعه والتسلل إلى جذع الدماغ كانت آبرز آهداف هذا العمل في هذا العمل.

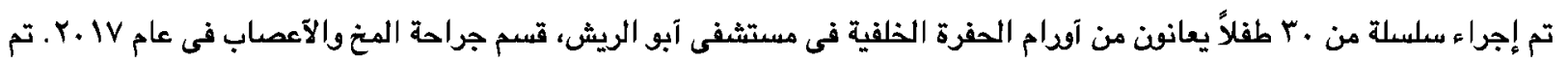

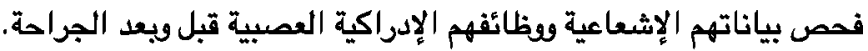

تطود الخرس المخيخى في آطفال (• r٪) في الآيام القليلة الآولى بعد الجراحة، V ذكود وץ إناث. تراوح العمر من سنتين إلى إثنى عثر

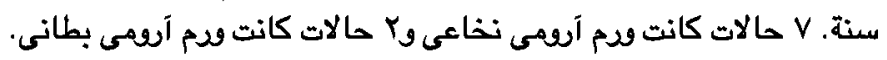
كان هناك تسلل فى جذع الدماغ فى معظم حالات الخرس المخيخى. تم حل الصمت في ^ حالات.

يمكن آن يحدث الطفع الدماغى غالباً بعد إستئصال آقدام الحفرة الخلفية في طب الآطفال في الآيام الآلئى بعد الجراحة بنتائج إيجابية.

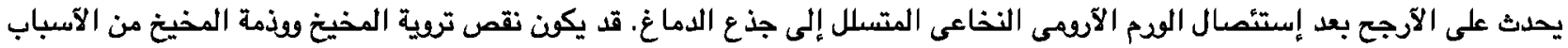

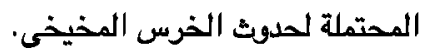

